\title{
水線抢よび肋骨線形状と造波抵抗
}

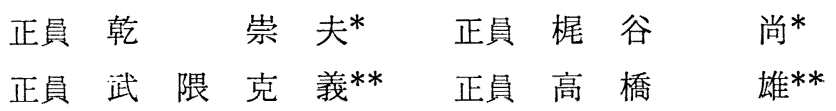

Influence of Designed Waterline and Frameline Forms on

Wave-Making Characteristics of Ships

By Takao Inui, Member Hisashi Kajitani, Member

Katsuyoshi Takekuma, Member TakeshiTakahashi, Member

Summary

According to the slender ship theory, the wave-making resistance of ships is definitely determined by the sectional are a curve alone as far as the so-called, end effect' terms are neglected. As a preliminary verification to this conclusion, a set of three symmetrical models with $C_{B}=0.55(L / T=$ 20) are tank-tested.

From the presently obtained results a tentative conclusion may be drawn that the designed waterline form atF. P. $\sim 81 / 2$ affects the wave-making characteristics of ships as seriously as the sectional area curve.

細長船理論1)によると，いわゆる端部影響の項を除けば造波抵抗は横切面積曲線の形だけでさまる。船型を 設計する場合の手順は対象や方法によつて必ずしも一定しないが，横切面積曲線をきめるところまでが第一段 で，ついで第二段として水線，胁骨線あるいはバルブの形など，よりこまかい線図そのものがきめられてゆくこ とが多い。従つて細長船理論の結論がそつくりそのまま通常の船型設計に適用できるのであれば，それのるたら すメリットは非常に大きい。上記の結論がぞこまで実際と一致するかを，適当な計画にもとづいた実験によつて たしかめておくことはこの意味でぜひ必要である。

この種の実験は, 要するに横切面積曲線を一定に押えて拈いて, 肋骨線形状をいろいろに变化させたシリーズ について比較をすることになるが，これまでの方法では变化のさせかたにあるひとつの理論的根拠というのがな く，ただ漠然とUとか $V$ とかの表現で適当に変えてきた。しかしこれでは理論的定量的な取扱いに不便であるば かりでなく, 船の端部から中央にかけて胁骨線の形状がいろいろに変化してゆく, その variation に全体とし てどれだけの型があるかをつかむことができない。

このような場合に，等価吹出し分布の概念を用い，まず全体としてどのような吹出し分布のパターンがありう るかを考え，ついで代表的なパターンにつきそれが表わす船型を流線追跡法で求めるという方法が考えられる。

以下の小論では, はじめにこの考方方の基礎, とくに細長船理論とのつながりについて述べ, ついでこれを応 用しておこなつた若干の水槽実験の結果について報告する。

ここで用いた方法は, 等価吹出し分布という概念をなかだちとして, 数学的アプローチともいえる細長船理論 （扣よひ極小抵抗理論）と工学的アプローチたる流線追跡法とを両者つなぎあわせたるのである。るともとこの 2つのアプローチは長所, 短所が拈もてうらになつている面があり, ある意味で相補的である。船型設計に造波 抵抗理論を有効に活用してゆくには，それぜれの長所をいかし，適当なところでバトンタッチするというリレー 方式を開発してゆくことも大いに必要なことであろう。このような考え方がこの報告の基礎になつている。

原稿受付 昭和 41 年 7 月 10 日

*東京大学工学部

**三菱重工業長崎研究所 


\section{1 細長船理論の基礎仮定}

細長船理論は理想流体を対象とした線型理論のひとつであるが，基礎仮定としてつぎの 3 ある。

(a) 船型条件 : $\beta=B / L \ll 1, \tau=2 T / B \approx 1$,

(b) 力学的条件の $1: b / \lambda(\theta) \ll 1$

$$
\text { ここに } \lambda(\theta)=\lambda_{0} \cos ^{2} \theta=2 \pi \cos ^{2} \theta / K_{0}
$$

(c) 力学的条件の $2: \beta \ll K_{0} l$,

ただし $L(=2 l), B(=2 b), T$ はそれぞれ船の長さ, 幅, 契水, $\lambda(\theta)$ は $\theta$ 方向素成波の波長, $\lambda_{0}$ と $K_{0}$ と はそれぞれ 2 次元自由波の波長拈よび波数である。

上記 3 条件のうち，船型条件（a）は通常の船型の場合まず満足されていると考兄てよい。条件（b）は船の つくる波が船体によつてこわされないための条件で, これから，この理論が適用しらるフルード数 $F_{n}$ の下限が きるる。条件 (c ）は自由表面が固体壁とみなしらるための条件で $F_{n}$ の上限を与兄る。

(4) 式を書直すと

$$
F_{n} \ll(L / 2 B)^{1 / 2},
$$

がえられるが, 排水量型船船では $F_{n}$ 数の最大値はたかだか 0.5 の程度であり，一方 $(5)$ 式右辺の值は $1.5 \sim$ 2 の程度であるから，（5）式すなわち条件（c）はまず問題ない。これに反して残る条件（b）には問題があ る。もともと細長船理論は数学的な吟味に耐えうる self-consistent な理論であることが，その特長となつてい るだけに，この条件を無視するわけにはゆかない。（3）式に拈いて， $\theta \rightarrow \pm \pi / 2$ で $\lambda(\theta) \rightarrow 0$ であるから，船の 半幅 $b$ が有限であるかぎり，素成波領域の全体について（2）式が成立するような $F_{n}$ の下限を定めることは できない。ただ実際問題としては幸いに $\theta \rightarrow \pm \pi / 2$ の素成波成分が受けもつ造波抵抗の寄与はゼ口に極限するか ら, $\pi / 2$ よりやや小さい $\theta_{1}$ をきめ, $|\theta|=0 \sim \theta_{1}$ の範团で（2）式が成立すればよいということに解釈してる大 きな誤りはない。同をどの程度にとるかは，波がぞの程度まで消光ればよいかによつてきまる。ヨコ波だけを 対象にすれば $\theta_{1}=35^{\circ}$ 程度を考光ればよいが，最近のように船型が次第によくなつてくると，ヨコ波だけ消した のでは不十分であつてタテ波もかなりのところまで消えることが要求されてくる。この意味で $\theta_{1}=60^{\circ} \sim 70^{\circ}$ 程 度にとるのが適当であろう。いまかりに $\theta_{1}=60^{\circ}$ ととると, 基準波長 $\lambda_{1}$ は

$$
\lambda_{1}=\lambda\left(\theta=60^{\circ}\right)=\frac{1}{4} \lambda_{0},
$$

となり，（2）式すなうち，条件（b）は次のように書ける。

$$
F_{n} \gg\left(\frac{1}{\pi} \cdot \frac{B}{L}\right)^{1 / 2}
$$

(7) 式右辺の值は $L / B=10,5$ に対して, それぞれ $0.178,0.252$ となるから, 通常の $L / B=5 \sim 7$ に対し ては $(7)$ 式を満足する $F_{n}$ の下限として少くとも 0.30 以上を予想しておく必要があろう。この值はタンカー 船型はもちろんライナ一船型でもその常用フルード数より高いので十分注意しなければならない。

さて, 周知の上 5 に細長船理論は 3 次元の吹出し分布から出発する。いま Lamb の定義による吹出し強さ $V \cdot m(\xi, \eta, \zeta)$ が船体内部の適当な分布面の上に連続的に分布しているとし, このような連続的吹出し分布が 一定速度 $V$ で長さの方向に直進運動するときの造波抵抗 $R_{w}$ の表示式を書く。この段階で上述の 3 つの条件を 入れて, パラメーター $\beta$ につて展開し， $\beta$ が1に比し十分小さいとし， $\beta$ の最低次の項のみに注目すると, 最 後に

$$
\begin{aligned}
& R_{w}=-\frac{\rho}{2 \pi} V^{2} l^{2}\left[\int_{C(1)} m\left(1, \eta, \zeta^{\prime}\right) d s^{\prime} \int_{C(1)} m(1, \eta, \zeta) \ln \left[\frac{1}{4} \gamma \gamma_{0}\left\{\left(\zeta^{\prime}+\zeta\right)^{2}+\left(\eta^{\prime}-\eta\right)^{2}\right\}^{1 / 2}\right] d s\right. \\
& +\int_{C(-1)} m\left(-1, \eta^{\prime}, \zeta^{\prime}\right) d s^{\prime} \int_{C(-1)} m(-1, \eta, \zeta) \ln \left[\frac{1}{4} \gamma \gamma_{0}\left\{\left(\zeta^{\prime}+\zeta\right)^{2}+\left(\eta^{\prime}-\eta\right)^{2}\right\}^{1 / 2}\right] d s \\
& -2 \pi M(1) M(-1) Y_{0}\left(2 \gamma_{0}\right)-2 \pi M(1) \int_{-1}^{1} M^{\prime}(\xi) Y_{0}\left(\gamma_{0} \overline{\xi-1}\right) d \xi \\
& \left.+2 \pi M(-1) \int_{-1}^{1} M^{\prime}(\xi) Y_{0}\left(\gamma_{0} \overline{\xi+1}\right) d \xi+\pi \int_{-1}^{1} d \xi^{\prime} \int_{-1}^{1} M^{\prime}\left(\xi^{\prime}\right) M^{\prime}(\xi) Y_{0}\left(\gamma_{0} \overline{\xi^{\prime}-\xi}\right) d \xi\right],
\end{aligned}
$$

がえられる。こに

$$
(\xi, \eta, \zeta)=(x / l, y / l, z / l),
$$




$$
\begin{aligned}
\gamma_{0} & =K_{0} l, \\
M(\xi) & =\int_{C(\xi)} m(\xi, \eta, \zeta) d s,
\end{aligned}
$$

で $と$ はオイラーの常数 $0.5772 \cdots \cdots, Y_{0}$ は第 2 種ペッセル関数である。（ 8 ) 式右辺は全体で 6 項からなるが, そのうちのはじめの 2 項は吹出しの端部の值 $m( \pm 1, \eta, \zeta)$ だけできまるので，これを端部影響 (end effect) の 項といい, 他の項と区別する。残り 4 項は吹出しの横切面内での積分 $M(\xi)$ 特よびその一次微係数 $M^{\prime}(\xi)$ で与 えられ，断面内のこまかな吹出し分布には関倸しない。各断面での吹出し総量 $M(\xi)$ は無次元の横切面積曲線

$$
\begin{aligned}
& S(\xi)=A(x) / b^{2} \\
& \text { ここに } A(x) \text { は横切面積, }
\end{aligned}
$$

と次式

$$
M(\xi)=-\beta S^{\prime}(\xi),
$$

で結ばれるから，この部分の $R_{W}$ への寄与は横切面積曲線が変らないかぎりその值も変らない。

\section{2 吹出し分布の型}

横切面積曲線一定の条件下に肘骨線の傾向を船首から中央にいたる閒いろいろ変化させるに当つて，各断面の 形は前後の断面形と全く無関係にきめられるわけではなく，当然全体としてなめらかな fairness が保たれねば ならない。それには船型を直接数式表示するか，以下に述べる等価吹出し分布から出発するか，2つの方法が考 えられる。しかし前者では無数に考えられる variation に統一的な見解を与えることが困難であつて, その点後 者の方法がすぐれている。

さて $M(\xi)$ が一定の条件下で, $m(\xi, \eta, \zeta)$ の variation を考えるに当つて, 水線面積にある程度の制限を設け ないと船として基本的に重要な復原性が不足し, 実際には使用できないような船型が含まれてくるおそれがある。 そこでほぼこれに対応する副条件として計画契水面 $\xi=0$ に抈忟る吹出しの midship に対するモーメント

$$
L=\int_{-1}^{1} m(\xi, \eta, 0) \cdot \xi d \xi
$$

がある值より小さくならないようにする。

吹出し分布 $m(\xi, \eta, \zeta)$ が次式

$$
m(\xi, \eta, \zeta)=m_{1}(\xi) \cdot m_{2}(\zeta)
$$

のように長さ方向の関数と契水方向の関数との積で表わされるいわゆる分離型は, Weinblum によつて elementary ship とよばれ, 理論とくに数学的アプローチではこの場合だけが主として取扱われている。その理由は

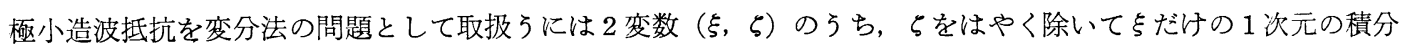
方程式に变形しなければ, 解析的処理ができないからである。従つて積分方程式の形で問題を考えてゆく数学的 立場では，これまでのところ下記の場合だけが取扱われている2)。

(1) $m_{2}(\zeta)=1$ で $T$ が無限大（無限契水船）

(2) $m_{2}(\zeta)=1$ で $T$ が有限,

(3) $m_{2}(\zeta)=1-\zeta^{4}$ ( $T$ 有限),

しかしながら実際に使用されている船型は，これよりもだいぶ複雑で，肋骨線の傾向は船の端部から中央にい たる間に微妙な変化を示しているのが普通であり，胁骨線形状が船の全長にわたつてひとつの型を保持している 例は皆無といつてもよい。従つてどうしても非分離型を含めて問題を考えねばならないし，また上述の極小抵抗 理論に括ける理論解析上の制約ということもあつて, 非分離型の場合にどうなるかという点にこそもつとも大き な関心がもたれる。

さてこのような非分離型の吹出し分布を取扱らには, たとえば，

$$
m(\xi, \zeta)=\sum a_{i} \xi^{i}+\zeta \sum b_{i} \xi^{i}+\zeta^{2} \sum c_{i} \xi^{i}+\cdots,
$$

とすればよい。もつとも胁骨線形状の変化は造波抵抗に対してそれ漂ど鋭敏ではないので, 将来はとすかくす現 段階でこの種の実験計画を立てるに当つては，(16) 式右辺のはじめの 2 項まで，すなわち 

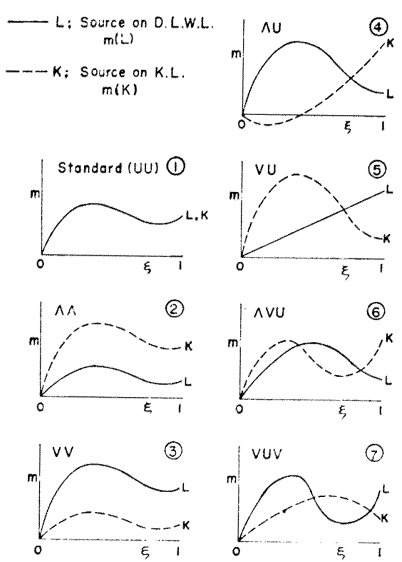

Fig. 1 Typical patterns for Source Distribution $m(\xi, \zeta)$

分であろう。この場合各横切面内の吹出しの契水方向分布は直線的な変

化を示すことになる。このようにして考兑られる吹出し分布の型を並べ てみたのが Fig. 1 である。図は前後対称船型の前半部船体に括ける等 俩吹出しの弓計画契水 $\zeta=0$ と, 分布面の底部 $\zeta=t$ とに抢ける吹出 乙強さ $m(L), m(K)$ の $\xi$ 方向, すなわち たもので $\xi=0$ が中央, $\xi=1$ が船首位置に対応する。パターンは全体 で 7 種考兄られる。(1)は基本型で契水方向に一様な分布である。(2) と (3) は分離型（またはこれに近いるの）で，(2)は全体にわたつて下らくらみ (いわゆる逆Vでこれを記号 $\Lambda$ で表示する)，(3)はその反対のいわゆる V型である。(2)場合には中央横切面がバルジつきのような形となり商 船の型としては適当かどらか, また復原性にも問題を残しがちな船型で ある。(4)以下(7はいずれも非分離型であつて, 前 3 者にくらべて一段と 複雑になつている。(4)は船首付近で $\Lambda$ （逆 $\mathrm{V}$ ), すなわちバルブ状とな り，中央では $\mathrm{V}$ ，(5はその反対沿船首付近で $\mathrm{V}$ ，中央で $\mathrm{U}$ となつてい る。図の中に記入してある $\Lambda$ や VU は以上のことを意味している。 (従来 UV というと前半部が $\mathrm{U}$, 後半部が $\mathrm{V}$ とらように用いられてい たが，ここでは前後対称船型のみを考学ており，前半部船体の範囲で，船首と中央とで吹出し分布およびそれか、 ら導かれる胁骨線形状がどの上うな傾向になつているかを表示している)。最後の6、（〕はそれぞれ(4)，(5)をさ らに複雑にしたもので, $m(L)$ と $m(K)$ との大小関倸が船首から中央にいたる間で 2 回変つている場合である。 これらよりもさらに複雑なパターンも考穴られなくはないが, 船型としてみた場合あまり意味はないので一応こ の 7 種の変化を考慮しておけば十分である。

\section{3 応}

用

前節に述べた考方方を $C_{B}=0.58 \sim 0.60$ 程度の高速ライナーの前半部船型に適用してみる。この種の船型は浮 力中心が midship より後方にあり前半部の方が後半部よりもかなり fine であるから, 前半部のみについては $C_{B}=0.55$ ととる。喫水比は $L / T=20$ とし, このような前後対称船型を計画する。流線追跡によつてえられた。 船型がなるべく実用船型汇近い平底となるように，等価吹出しの分布面は船体縦中心線面をとらず，Pien ${ }^{3), 4)}$ によつて㧒張された，いわゆる 2 スケルトン (skelton) 分布とする。すなわち側曲面の形を

$$
\eta= \pm 0.12\left(1-\xi^{2}\right)^{2},
$$

ととり, その深さ $T_{0}$ を実契水 $T$ の 0.7 倍にとる。（長さの半分 $l$ で割つた無次元值は実契水が $t=0.10$, 分布 面の深さが $t_{0}=0.07$ となる)。

左右対称の wall-sided な側面（17）に吹出しを，またその底面 $\zeta=t_{0}$ には軸が鉛直方向を向く二重吹出しを“ それぞれ分布させる。後者は実底面 $\zeta=t$ がより一層平底に近づくために加えたものである。

まずはじめに基本型として Fig. 1 の11相当するものとし次式

$$
m(\xi)=1.393240 \xi-0.710861 \xi^{2}-2.494148 \xi^{3}+2.042789 \xi^{4},
$$

の分布を光らで，底面の鉛直二重吹出しとして，

$$
B(\xi, \eta)=0.1 \xi^{2}\left(53.333 \eta-888.883 \eta^{2}+3703.68 \eta^{3}\right), \quad(-1 \leq \xi \leq 1)
$$

を扣く。(18) 式からただちに各横切面での吹出しの総量 $M(\xi)$ は次式で与えられる。

$$
\begin{aligned}
M(\xi) & =2 \int_{0}^{t_{0}} m(\xi) d \xi=2 t_{0} \cdot m(\xi) \\
& =0.35 \times\left[1.398240 \xi-0.710861 \xi^{2}-2.494148 \xi^{3}+2.042789 \xi^{4}\right]
\end{aligned}
$$

また復原性に関係のある量として (14) 式の $L$ は

$$
L=2 \int_{0}^{1} m(\xi) \cdot \xi d \xi=2 \times 0.13=0.26,
$$

となる。

つぎに，(20)·(21）の条件のもとに吹出し分布を非分離型に抾張してみる。(16) 式の右辺のはじめの 2 項ま でとり, 


$$
m(\xi, \zeta)=\sum_{1}^{4} a_{i} \xi^{i}+\zeta \sum_{1}^{4} b_{i} \xi^{\imath},
$$

と扣き，末定係数 $a_{i} ， b_{i}$ を条件（20）に対応する

$$
\left.\begin{array}{rl}
1.398240 & =a_{1}+\frac{t_{0}}{2} b_{1} \\
-0.7108613 & =a_{2}+\frac{t_{0}}{2} b_{2} \\
-2.494148 & =a_{3}+\frac{t_{0}}{2} b_{3} \\
2.042789 & =a_{4}+\frac{t_{0}}{2} b_{4}
\end{array}\right\}\left(\left(t_{0}=0.07\right)\right.
$$

と，条件（21）に対応する

$$
0.13=\sum_{1}^{4} \frac{a_{i}}{i+2}
$$

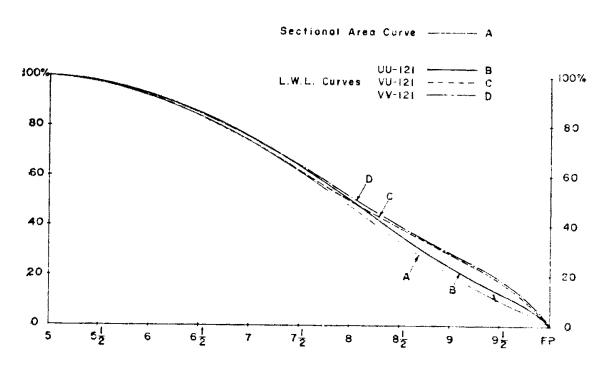

Fig. 2 Sectional Area Curve and Designed Waterlines

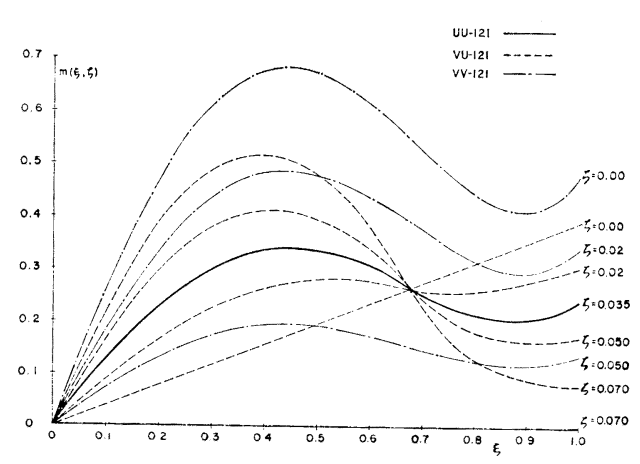

Fig. 3 Selected Source Distributions

すなわち

$$
0.13=\frac{a_{1}}{3}+\frac{a_{2}}{4}+\frac{a_{3}}{5}+\frac{a_{4}}{6},
$$

そから定める。変数 8 コに対し, 条件式の数は 5 ב であるから，これだけでは一義的にきまらない。つ まりいくらでも variation はありうるが, そのうち ஆつとも簡単なるのとして,

$$
a_{1} \neq 0, \quad a_{2}=a_{3}=a_{4}=0
$$

とおくと, 変数は全部で 5 コとなり, 次式のように きまる。

$$
\begin{aligned}
& m(\xi, \zeta)=0.39 \xi \\
+\zeta & \left(28.80685 \xi-20.31032 \xi^{2}\right. \\
& \left.-71.26137 \xi^{3}+58.36540 \xi^{4}\right),
\end{aligned}
$$

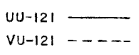

$v V-121$

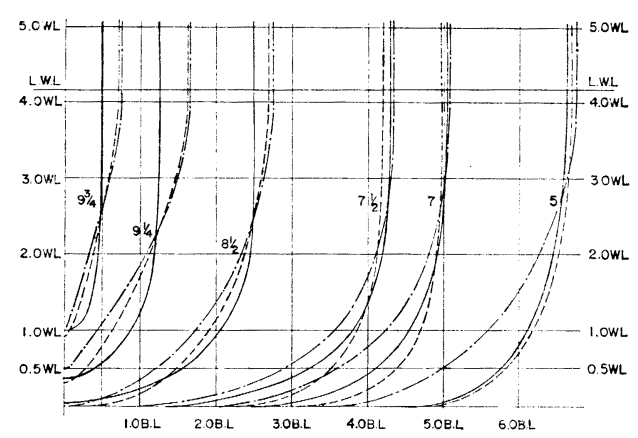

Fig. 4 Body Plans

Fig. 2 の曲線 Aが，これらの吹出し分布から流線追跡法で求めた実際の船型の横切面積曲線を示し，B.CD は計画契水線の形を示している。Fig. 3 は側面に括かれた吹出し分布の長さ方向の变化をら契水をパラメーター として表わしたもので, 太い実線で示したのが基本型（18）式の分布である。Fig. 4 は正面線図で，これらの図 では基本型に相当するるのを UU-121，(27）式に対応するものを VU-121 と記してある。後者は前節 Fig. 1 のパターン(5に属するものである。な拈 VU-121 について採用した底面二重吹出しは

$$
B(\xi, \eta)=0.06543 \xi-0.05454 \xi^{2}-0.01088 \xi^{3}, \quad(-0.8 \leq \xi \leq 0.8)
$$


底面二重吹出しは軸が鉛直であるから，その効果は流体をその断面内で上または下に向けるだけであつて横切 面の形は変えるが, その面積は不変である。Pien は二重吹出しのほかに, 吹出しをも考慮しているが, 実用上 その必要はなく, 鉛直二重吹出しのみで十分であり, かつその方が上述の条件を満足するので成上好都合であ る。

上述の 2 つの船型 UU-121 と VU-121 とを比較すると船首付近の水線形状にかなりの差があることが Fig. 2 からあきらかである。そこで, 2 番目の船型 VU-121 と計画契水線の形状が $\xi=0.7 \sim 1.0$ (横切面番号で $8{ }^{1 / 2}$ Ｆ.P.）の範囲で酷似して拉り，前節のパターン(3に属するものを 3 番目の船型として求めてみた。この場合, 助骨線の形状が船首から中央にいたるまでVになつているので，復原性はあまる傾向になり，これを無理に押兄

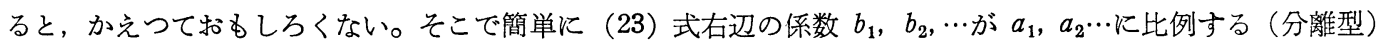
としその比例常数を中とする。

$$
b_{i}=p \cdot a_{\imath},
$$

このとき (22) 式は，

$$
m(\xi, \zeta)=(1+p \cdot \zeta) \sum_{1}^{4} a_{i} \xi^{t}
$$

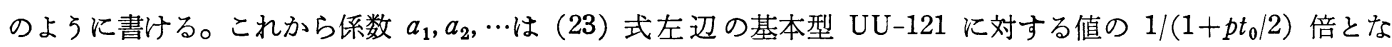
る。 $p$ としてろいろの值が考えられるが $m(K) \geq 0$ の条件を考えると, すつとす極端な場合として $m(K)=0$ より

したがつて

$$
1+p t_{0}=0 \text { あるいは } p=-1 / t_{0}\left(t_{0}=0.07\right),
$$

すなわち $m(L)$ の值は基本型のそれの 2 倍になつている。このと このよ5にしてきめた吹出し分布から求めた船型をVV-121 とし，前述の 2 隻と合わせて Figs. 2 4 亿示して ある。この船型に対する底面二重吹出しは次式の通りである。

$$
\begin{aligned}
B(\xi, \eta)=\eta & 13.694406 \xi-217.57531 \xi^{2}+1122.7798 \xi^{3}-2164.7894 \xi^{4} \\
& +1402.8319 \xi+\eta^{2}\left(-321.60403 \xi+4681.42053 \xi^{2}-20328.298 \xi^{3}\right. \\
& \left.+27021.405 \xi^{4}-9389.8950 \xi^{5}\right)+\eta^{3}\left(2199.2080 \xi-31123.073 \xi^{2}\right. \\
& \left.+134839.09 \xi^{3}-211253.55 \xi^{4}+206739.48 \xi^{5}\right),(-0.8 \leq \xi \leq 0.8)
\end{aligned}
$$

Table 1 Calculated End Effect' Terms $\left(C_{W} \times 10^{4}\right)$

\begin{tabular}{c|c|c|c|c|c}
\hline$F_{n}$ & 0.15 & 0.20 & 0.25 & 0.289 & 0.354 \\
$K_{0} L$ & 44.44 & 25 & 16 & 12 & 8 \\
UU-121 & 0.813 & 1.811 & 2.587 & 3.087 & 3.791 \\
VU-121 & 1.303 & 2.302 & 3.007 & 3.577 & 4.288 \\
VV-121 & 1.595 & 2.593 & 3.389 & 3.868 & 4.573 \\
\hline
\end{tabular}

上述 3 船型については細長船理論と流線追跡法と の両方から造波抵抗を計算することができる。とく に前者では $(20)$ 式の $M(\xi)$ が一定であるから, 3 船型間の差だけを求めるのは端部影響の項だけの 計算ですむ。第 1 表にその結果を $C_{W}=R_{W} /(\rho / 2$ $\left.V^{2} L^{2}\right)$ の形で示す。これによると基本型 UU が一
Table 2 Particulars for Tested Models $(L=2.5 \mathrm{~m})$

\begin{tabular}{c|c|c|c}
\hline Model & UU-121 & VU-121 & VV-121 \\
\hline$L / B$ & 6.263 & 6.22 & 6.127 \\
$L / T$ & 20 & 20 & 19.38 \\
$B / T$ & 3.194 & 3.214 & 3.162 \\
$C_{B}$ & 0.547 & 0.550 & 0.522 \\
$C_{p}$ & 0.581 & 0.581 & 0.582 \\
$C_{M}$ & 0.947 & 0.950 & 0.896 \\
$\Delta /\left(\frac{L}{10}\right)^{3}$ & 4.367 & 4.403 & 4.403 \\
$S /\left(\frac{L}{10}\right)^{2}$ & 16.91 & 17.14 & 16.72 \\
$A_{w} /\left(\frac{L}{10}\right)^{2}$ & 9.50 & 9.66 & 9.84 \\
$I_{w} /\left(\frac{L}{10}\right)^{4}$ & 1.280 & 1.280 & 1.375 \\
$K$ (Hughes) & 0.28 & 0.34 & 0.30 \\
\hline
\end{tabular}

番小さく, $\mathrm{VU} \cdot \mathrm{VV}$ の順に大きくなつているが，後述の実験と比較すると， $F_{n}=0.30$ 以下でその傾向は大体よ くめつているようである。

\section{4 実験}

前節の 3 船型につき $2.5 \mathrm{~m}$ 模型の水槽試験を実施した。抵抗試験, 船側波形, 波紋観測の 3 つを併用したが とくに後者を重視した。乱流促進用の stud は高さ $1.5 \mathrm{~mm}$ の plates tud を. s. $9 \frac{1}{2} 2$ に $10 \mathrm{~mm}$ の間隔で 
植えた。摩擦式は Hughes 式を用いた。第2 表には 供試模型船の要目扣よび形状因子 $K$ の值を示してあ る。Kには若干の差がみられるが実験当時のレールの 状態が必ずしも十分良好とはいえなかつたのである程 度の誤差を含むるのと想像される。

Fig. 5 の船側波形，拉よび Fig. 6, 7 の波紋写真か らきわめて明瞭なことは, UU が VU, VV と非常。 にちがうこと，怙よび VU.VV が非常によく似てい ることである。この傾向はある程度は予想されたこと であるが，予想よりもはるかに顕著な結果が表われて いる。横切面積曲線が同じです, F.P から s.s. $8^{1} / 2$ あ たりまでの胁骨線形状，とくに計画契水線の形状が異

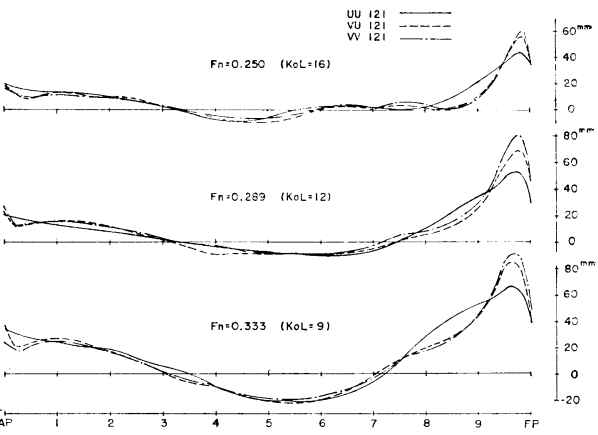

Fig. 5 Wave Profiles なると造波特性は相当に变ることがわかる。もつともその差は， $F_{n}$ がます行従つて次第に小さくなつてくるこ とはたしかであつて，この傾向は細長船理論の基礎仮定からもらなづける。

Fig. 8 は抵抗試験の結果を造波抵抗係数 $C_{W}=R_{W}$

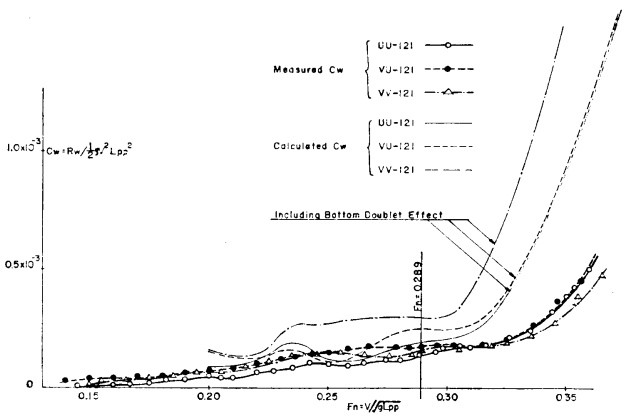

Fig. 8 Resistance Test Results $/\left(\frac{\rho}{2} V^{2} L^{2}\right)$ の形で示す。波形観測の結果と対応し て, $F_{n}<0.31$ ではUU がもつとも低い $C_{W}$ 值を 示し, 他の 2 隻 VU.VV は平均として 1.5 倍ほと の大きさとなつている。 $F_{n}>0.32$ ではこの傾向が 反転し，UU・VU がほとんど同じ值を示し，VVが これよりも低い $C_{W}$ を示す。造波抵抗理論からは このような逆転の傾向は説明できない。また形状因 子Kが $F_{n}$ によつて变化すると考えれば Fig. 8 の ような比較の方法自体に問題が残される。図には参 考として前節で求めた吹出し，二重吹出しの系に対

する $C_{W}$ の理論值を記入してある。繁雑をさけ尺 ため底部二重吹出しを除いた側面吹出しだけの計算については示してないが， $F_{n}=0.29$ でみるとU, VUで は二重吹出しを加えることによつて $C_{W}$ はかなり大幅にまし，VVではほとんど変つていない。この底部二重 吹出しは横切面の形は変えるが面積にはほとんぞきいてこない。細長船理論の立場では $C_{W}$ の变化はないはず であるが計算の方法によつて結論が変つてくる。このあたりにる今後さらに究明しなければならない点が残され ている。

以上等価吹出し分布から出発してシリーズ船型の計画を立てる方法について述べ, その応用例として, 横切面 積曲線が一定で，水線形状・助骨線形状を異にする 3 種の船型間の比較を行なつた。このシリーズで比較すべき パターンはほかにも，たと亲 Fig.1 の(4)など，まだ残されているがこれらはバルブつき船型を含めて次の機 会にとりあげたいと考光ている。

この報告に関係のある実験には小川清勝君, 計算および解析には足達宏之, 山口真裕両君の協力をえた。記し て愿く謝意を表する次第でる。

\section{References}

1) Maruo, H. : J.Z. K. 112 (1962)

2) Maruo, H. : Fifth Symposium on Naval Hydrodynamics (Bergen, 1964)

3) Pien, P. C. : Do.

4) Pien. P. C. : D. T. M. B. Tech. Rep. 2144 (1965) 


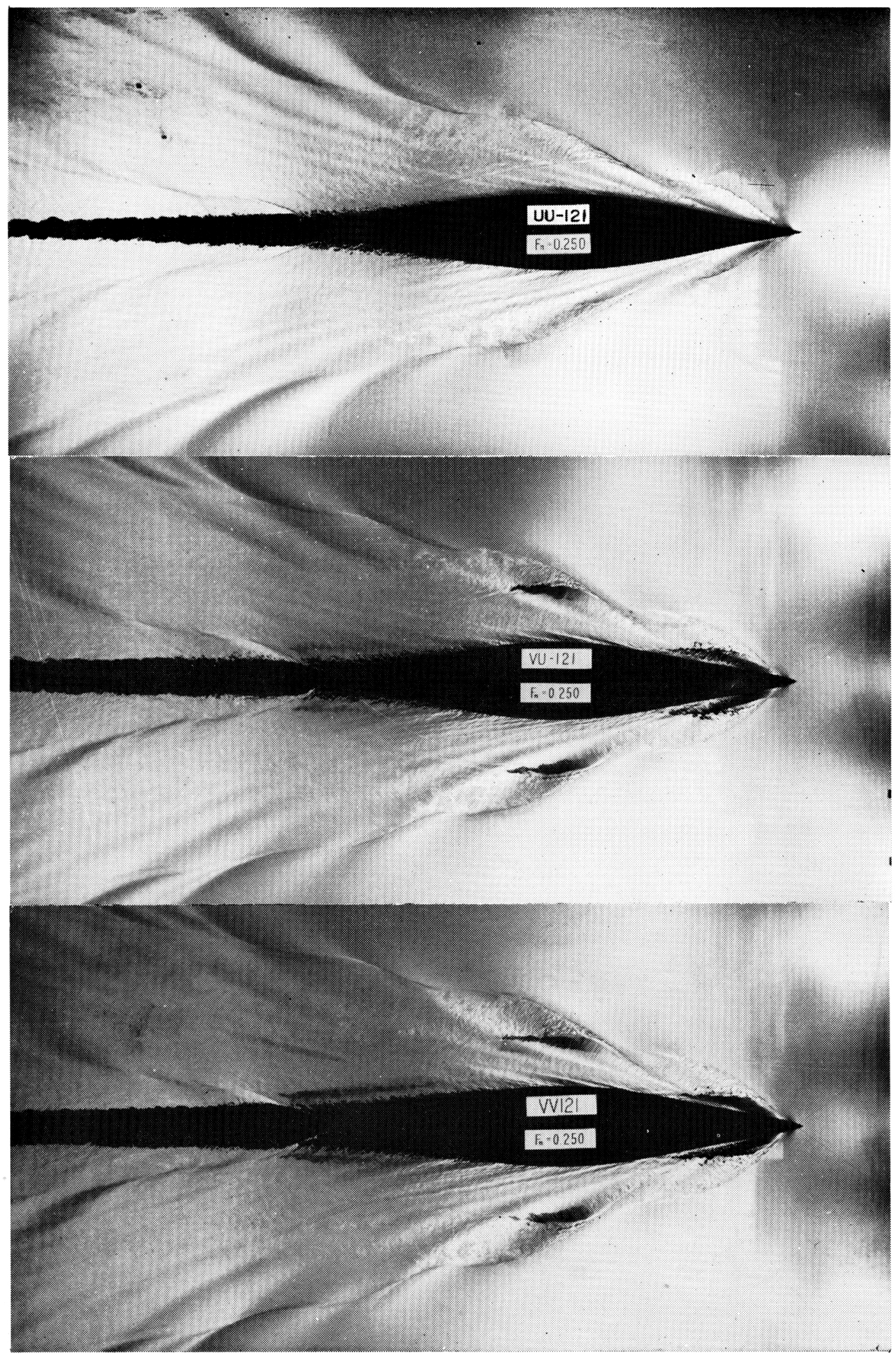

Fig. 6 Wave Patterns $\left(F_{n}=0.250\right)$ 

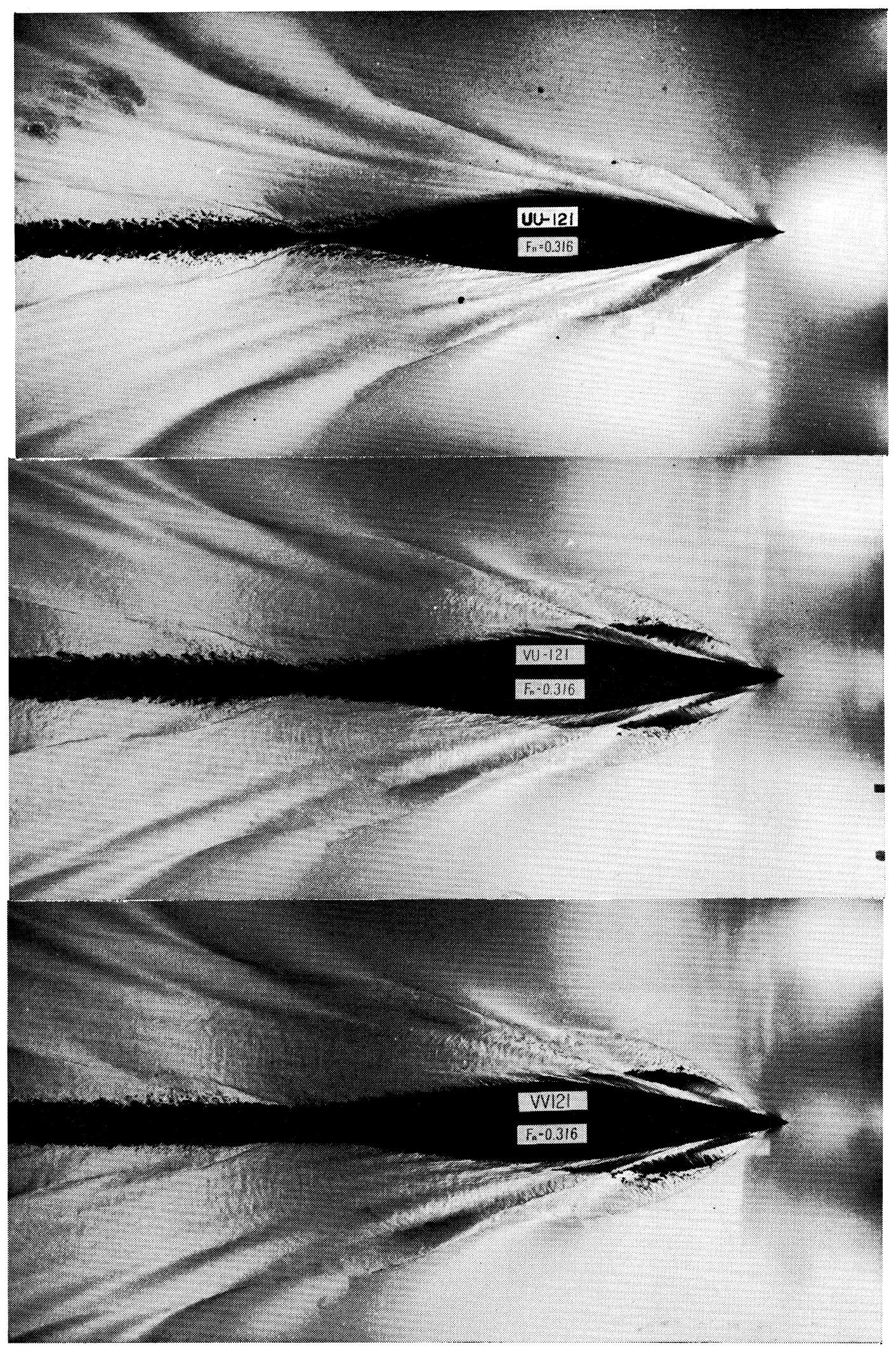

Fig. 7 Wave Patterns $\left(F_{n}=0.316\right)$ 